\title{
The back side of the postcard: Subversion of the island tourist gaze in the contemporary Mallorcan imaginary
}

\author{
Mercè Picornell \\ LiCETC, Universitat de les Illes Balears, Spain \\ m.picornell@uib.cat
}

\begin{abstract}
This article analyses the manner in which certain artists and activists in Mallorca have recently generated a counter-image of the traditional postcard, which essentially symbolises the tourist gaze. Taking examples from diverse sources, such as artistic pieces, memes, protest posters and underground comics, I analyse the mechanisms used to subvert the conventional tourist perspective of the island space. More specifically, I identify two strategies associated with the limitation of the space and time portrayed in the postcard. The confines of the space are manifest in the display of the off-camera and the critical anchorage of the image, while the limits of temporality are presented in a dystopic revision of the island map. To support the findings of this study, I have drawn on the ideas, theories and methods of island studies, tourism studies, postcolonial criticism and the rhetoric of images. The conclusions of this article aim to provide an interpretation of the complex emergence of a resistant social agency capable of creating its own portrayals of the island.
\end{abstract}

Keywords: Balearic Islands, island social movements, postcards, resistance art, tourism

https://doi.org/10.24043/isj.109 • Received November 2019, accepted March 2020

(C) 2020-Institute of Island Studies, University of Prince Edward Island, Canada.

\section{Introduction}

If the Balearic Islands are known within the realm of tourism studies, it is because the marketing strategies applied within the region are often ultimately projected elsewhere, going beyond island settings (Horrach, 2015). Local marketing is followed by a global impact. The latest phase of this tourism destination has manifested in the conversion of residential homes into overnight accommodations for visitors. This process has been studied from the perspectives of geography and anthropology: Ivan Murray, Ismael Yrigoy and Macià Blázquez (2017) have evaluated the recent evolution of tourism in the Balearic Islands; Sonia Vives and Onofre Rullán (2017) have analysed the touristisation of the city centre of Palma and the consequential dispossession of resident housing that it generates, and Marc Morell (2018) has considered its social and cultural consequences. The increase in the number of visitors fostered by the advent of this new lodging model - facilitated by online marketing platforms that make it difficult to limit, despite regulatory attempts by the local authorities - as an addition to the existing sun and sea hotel tourism and the booming tourism models that focus on sports, 
'rural' and luxury resorts, as well as the so-called urban 'boutique hotels'- has led to a general feeling of oversaturation (Valdivielso \& Moranta, 2019). The results are the beginnings of new social movements that speak out against the harmful effects of the unlimited growth of tourism (i.e. Ciutat per a qui l'habita or Terraferida). These protest movements have been dubbed by certain media as being "tourist-phobic" (Blanco-Robero, Blázquez-Salom \& Morell, 2018; Anywar, 2017). Criticism against the effects of tourism has a longstanding tradition in Mallorca. The discourses of these social movements now combine with others that began with the ecology movement during the 1970s as a political reaction to the overdevelopment of the island's land and its resultant destruction (i.e. Grup d'Ornitologia Balear, see Rallo, 2004; Buswell, 2011). Hence, ecological sustainability now takes on a still greater social dimension, associated with access to housing and working conditions within the hotel industry, as expressed in countless media. Visually, that discourse is often portrayed through the clearly defined perimeter of the island's territory with its maritime borders, as an indicator of the impossibility of overburdening a limited space.

In this article, I analyse diverse postcards and artistic responses that offer a subversive portrayal of the island region within a more extensive critical and artistic discourse (for a similar study applied to Lisbon, see Martínez-Tejero, 2018). For the purposes of this paper, the postcard is defined as both a support and a framework that regulates a specific manifestation of the imaginary of a place that is visited and inhabited at the same time. The postcard will serve as an emblem or summation of the specificity of what John Urry (2002 [1990]) refers to as the 'tourist gaze'. The 'tourist gaze' has already been studied in relation to other island contexts, from perspectives different from the one proposed here. Regarding the corresponding study on Malta and the Caribbean Islands, Annabel Black (1996, p. 113) and Elvira Putilato (1996, p. 155) cite the colonial determinants of the construction of an island image. In the case at hand today, this effect refers to the exoticization of the space, or as Phikipe Duke (2007) more aptly describes, the creation of an image that is both exotic and familiar and that translates the local culture, making it suitable for tourist consumption (see also Black, 1996, p. 113). In the context of Mallorca, the effects of tourism on the island imaginary have been studied from the perspective of the literary corpus of illustrious visitors (Moyà, 2017), as well as from that of cinematic portrayals that evolve with the changes in the tourist market (Brotons, Murray, \& Blázquez, 2016). All the same, Hazel Andrews (2011) analyses the way the tourist imagery of Magaluf is influenced by the expectations of British consumers. In general, the image portrayed does not focus on the authenticity or appropriation of the island's cultural or archaeological heritage — as noted by Johnson (2012) and Duke (2007) for the cases of Jersey and Crete- but rather on the creation of a landscape for relaxation. That landscape is associated with both a widespread imaginary of the tropical island and the image of peaceful Mediterranean wellbeing (Sala \& Casellas, 2015). This study takes this review of the imaginary a step further, by exploring the way that the island's local artists critical of the effects of tourism create an alternative image, parodying the stereotypes ascribed to the island while at the same time conveying a political message of cultural resistance.

As Marcus Banks (2007, p. 7) suggests, the act of viewing is never a natural action, but rather a culturally and moreover, historically specific experience. The tourist gaze is not only associated with a specific spatiality, but also with a specific temporality. Both its place and its time are reviewed in the critical proposals that I will be analysing below. The cases under study have a highly visual component and diverse origins, ranging from experimental 
artistic creations to underground products and/or pieces disseminated through social activist media. For the purposes of this paper, it is not the history, classification or inventory of these portrayals that interests me. Rather, they serve as the basic data that sustain a consideration regarding the opportunity of the island residents to configure a counter-image to the tourist gaze; in other words, an image that uses parody to subvert the way that tourism has shaped the perception of the island, drawing precisely on the formulae and features produced by tourism. Methodologically, this analysis has drawn on advances in tourism studies and island studies. Both fields have been prolific in exploring the way the imagination of a given place determines its conceptualisation and the activities carried out on its soil. This article aims to analyse the images themselves, as well as what those images are telling us about the agents that produce them. More specifically, I will be postulating that the postcard image counterwritings in contemporary Mallorca afford the preliminary formation of a local social and political island agency that often manifests itself in the confluence of creative people and activists and is shaped by the ambiguity implicit in the aesthetics and politics of resistance.

\section{Unbearable paradises and subverted postcards}

In 2015, the Fundació Mallorca Literària, an institution that reports to the Balearic Islands Government, launched the project 'Walking on Words', featuring seven island itineraries based on the texts of writers - local islanders and visitors alike-who have written about the island or while physically on-site. The project includes a website and a mobile phone application disseminated under the acrostic WOW. It opens with a sentence that Gertrude Stein wrote to Robert Graves when the latter decided to visit the island that would ultimately become his home: "Mallorca is a paradise, if you can stand it." Together, the project is presented as "a guided tour of the real Mallorca, revealing the delights of a paradise full of history, life and literature." Although this project is not solely designed for visitors, it would be erroneous to believe that an islander could ever be the second target of the texts that comprise it; firstly because according to the presentation, there is a 'we' to whom the 'delights' of the island will be revealed, therefore assuming that the person in question is unaware of them. Moreover, if we extend Stein's famous sentence to this supposed Mallorcan reader, it is assumed that the intensity of this paradise is unbearable, while at the same time forming part of the local island resident's daily life. This in turn would render Mallorcans - if I may make the joke-either insensitive to beauty or emotional superheroes. In a word, the presentation reproduces some of the clichés associated with the tourist portrayal, particularly those relating to island enclaves, which, according to Geoffrey Baldacchino (2008), are highly given to mythification processes. According to Pete Hay (2006), the metaphoric potential of the island notion can go so far as to replace the very reference of the island, and more so in touristification processes, where the creation of a fantasy image plays an essential role (Rojek, 1997, p. 53). Furthermore, the myth is not only lived as real for those who travel. It can in fact be materialised by creating places that fit in with the projected image, for example, by planting palm trees along Mediterranean seaside walks where pine groves once stood; or through the connoted portrayal of an abundance of water and green on the golf courses of an island that is often threatened by drought. Hay (2006) adds that island residents can be resentful of this excessive mythification of the space that they inhabit. 
In Mallorca, that 'resentment' sometimes translates to a critical and creative reinvention of the island image. While I do not aim to propose a genealogy of this image, it could be said that the subversive critique of the tourist image of the island was already emerging in the late 1970s in three types of registers: a) a register connected with experimental artistic production; b) a register stemming from environmental protection campaigns; and c) a register which uses popular forms of consumption to make a satirical comment on the difficult coexistence between residents and tourists. Frequently, the two former strategies come together, as occurs in the monographic issue of the magazine Neon de suro, published in April 1978 by a group of Mallorcan neo-avantgarde artists. The publications in this issue use promotional advertisements to discourage tourists from visiting the island. Hence, they manipulate an advertisement with the motto "It's better in the Bahamas," which, from one page to the next, gradually becomes "It's better in the fiction" (Figure 1). A face that could be characterised as that of a North American 'Indian'-according to the popular cinematic version of this ethnicity-begs us in different languages: "Please don't go to spend your holidays in Majorca." In fact, the characterisation of the islander as 'indigenous' is frequent in the imagery generated by the island's cultural resistance, appearing throughout the exhibition, while connecting with the characterisation of the island resident through a folkloric image that is at once exotic and harmless (Duke, 2007). This complex identification between indigenism and space in island contexts has been already pointed out by Adam Grydehøj, Yaso Nadarajah and Ulunnguaq Markussen (2020).

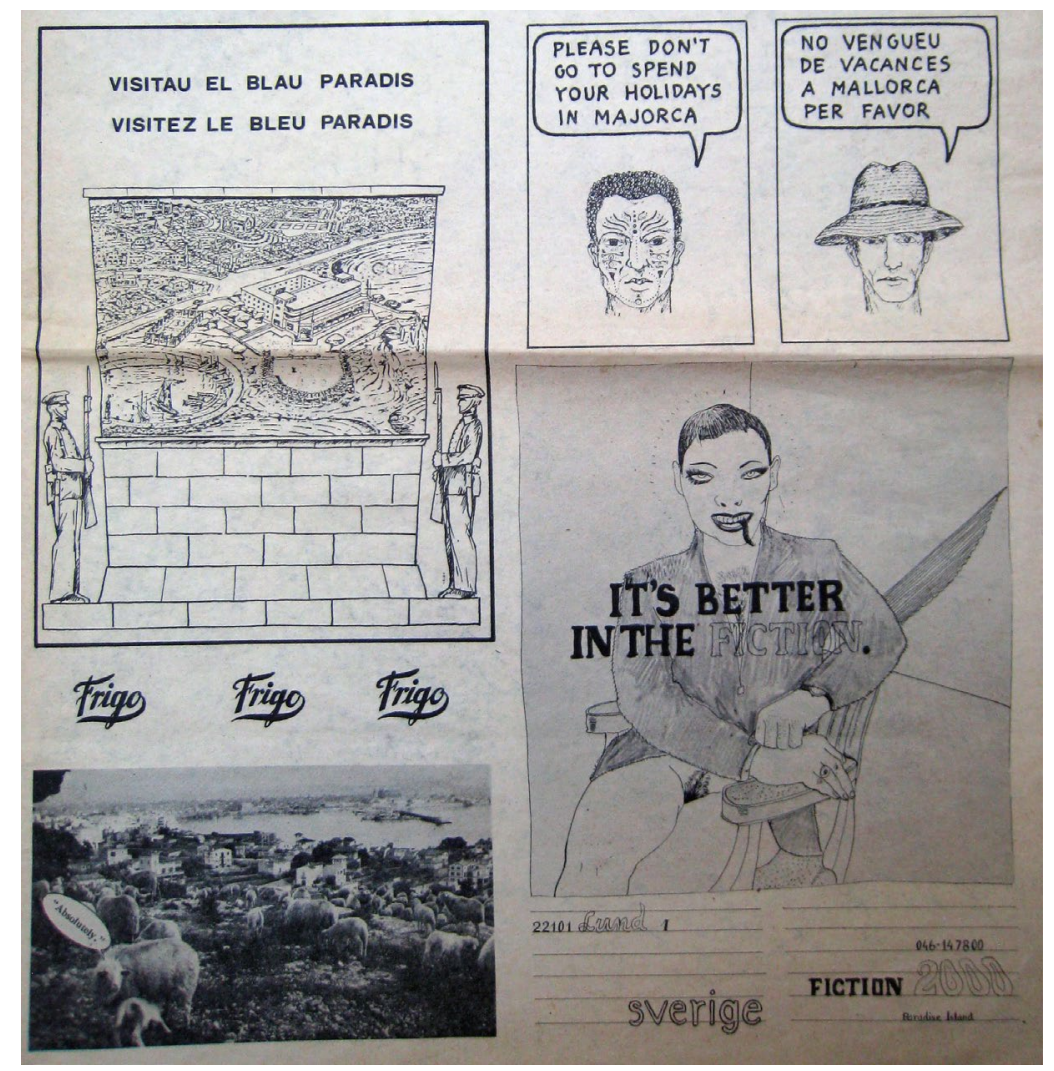

Figure 1. Passage from page 3 of the magazine Neon de Suro, April 1978.

The same year, Steva Terrades would present the work Document preservatiu (Figure 2), a set of 35 plastic envelopes that included a photo of a protest against the construction of the 
Palma-Inca motorway, along with a piece of gauze and surgical tape - symbolising the wound in the land - and a condom that in turn represented what ought to be 'preserved'-drawing on the Catalan word for condom, preservatiu-, therefore creating a play on words (Parcerisas, 2007, pp. 318-319). Here, the tourist image is replaced by that of protest.

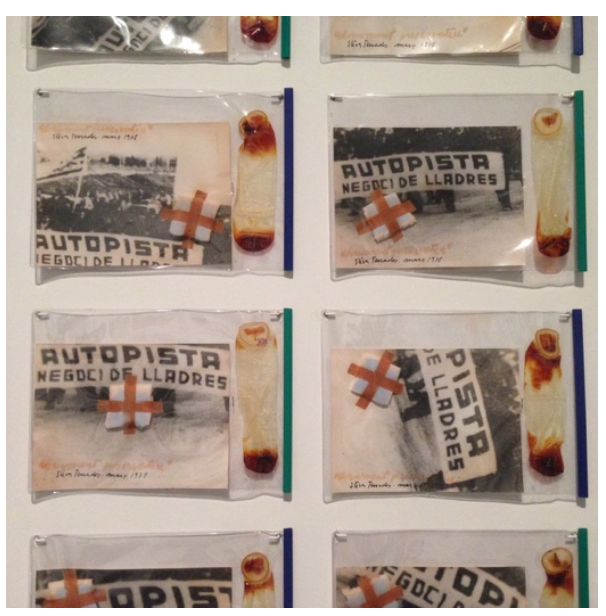

Figure 2. Photo of the installation by Steva Terrades 'Document preservatiu' (1978). Source: LaFotogràfica.

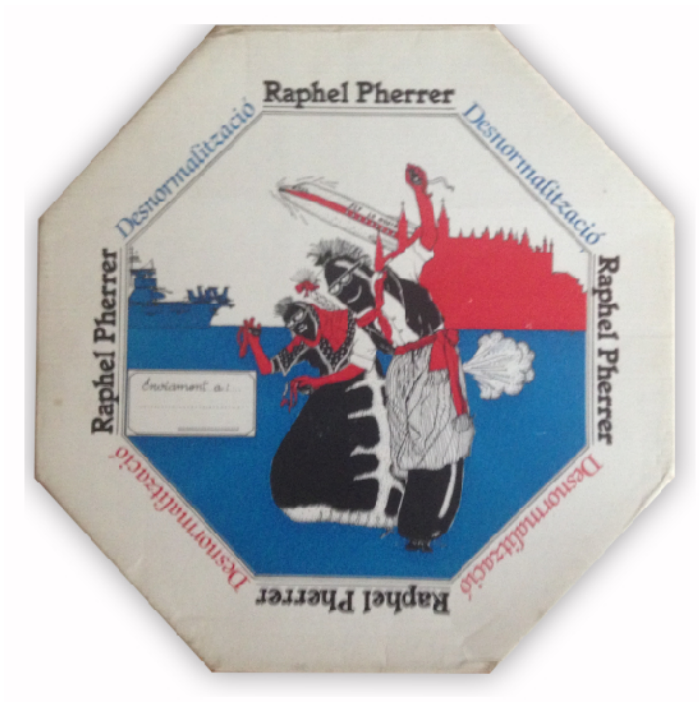

Figure 3. Front of the cover of the album 'Desnormalització', by Raphel Pherrer (1987).

In the 1980s, this critique would take on a more comical and innocent dimension in musical products such as 'Mallorcatur' (1988) by Raphel Pherrer and Carlos Garrido, which parody the tourist songs that promoted the commercial dissemination of the island as a destination in the Spain of the late Franco dictatorship (Vives, 2002). Nevertheless, it must be noted that many of the references in the songs may be difficult to understand for those who are unfamiliar with Mallorcan society and culture. Along a similar line of humour, in 1994, the musical group Ossifar-whose performances and albums enjoyed unprecedented success on the island-recorded the song 'Vacasiones en Mallorca', offering a version of the song 'Paradise of Love', by Los Javalollas, about the idyllic environment on the island with statements such as "cada día es fiesta en Mallorca" ("every day is a holiday in Mallorca"). In 
the new parodic 'version', the promotional discourse in English is placed in contrast with pyromaniacs, drugs, filth, etc. In 1987, Raphel Pherrer released another album titled, 'Desnormalització' ('De-normalisation'). The album was distributed in a format that resembled the typical ensaïmada boxes that are used to transport this emblematic Mallorcan pastry by plane. Designed by Vicenç Sastre, the cover displays the silhouette of Palma's main cathedral - probably the most recursive image on the island's tourist promotion postcardsflanked by a commercial airplane and a battleship, underscoring the two major 'invasions' on the island: that of the tourists and that of the fifth American fleet, which used to make a stopover in the harbour. The two main characters that appear in the foreground of the image are difficult to describe: they look like sobrassades - the typical Mallorcan cured meat-dressed in traditional garb and engaging in folkloric dances in scatological positions (Figure 3).

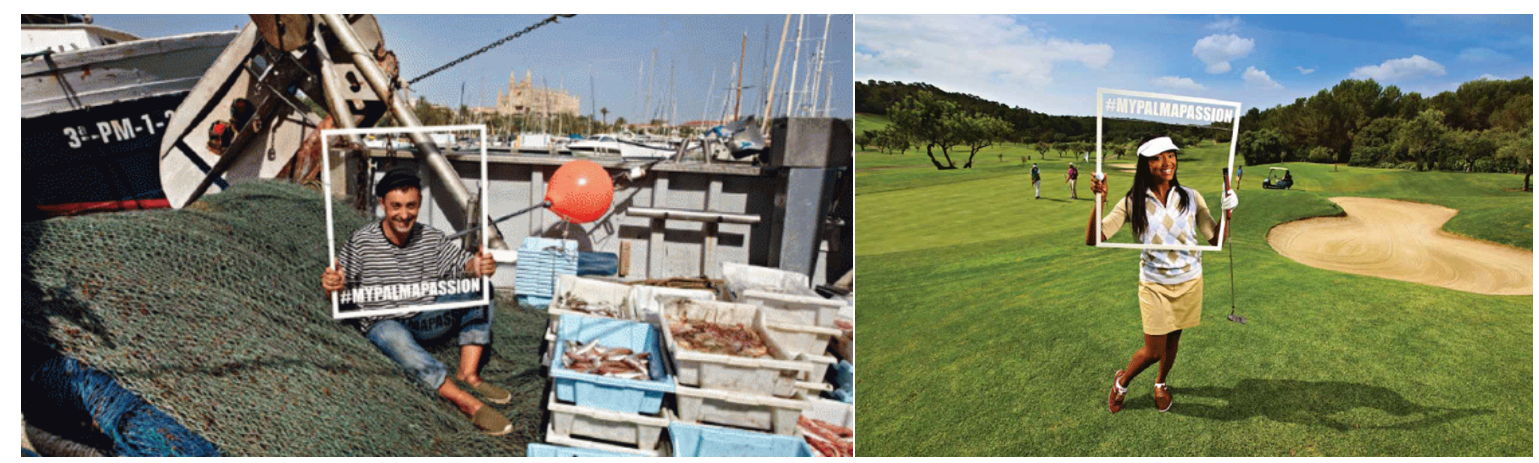

Figure 4. 'Passion for Palma' campaign.

This type of disruption of the emblematic image of the tourist postcard would become frequent in the critical discourses on tourism between the late $20^{\text {th }}$ century and the present time; in other words, precisely during the years in which the postcard would gradually lose its relevance as a means of communication. In the $21^{\text {st }}$ century, with the advent of selfies that can be posted in several different social media simultaneously, the postcard has virtually lost any communicative purpose that it may have had in the past. Still holding its position in the display stands of souvenir shops, however, it can be reappropriated from two different perspectives. On the one hand, it can be presented as something old and collectible, a friendly past that we can nostalgically look back on. Hence, for example, a documentary programme broadcast in 2016 on the local television channel IB3 was precisely titled Postals! (Postcards!) and covered the evolution of tourism from the friendly face of the experiences of residents and visitors, based on old postcards. The institutional tourism promotion campaign 'Passion for Palma' (Figure 4) also featured different residents of the city holding a photo frame meant to define part of their experience of the city, in a somewhat absurd sort of photo call that is nevertheless ironically illustrative of the liminal function of the tourist gaze, which isolates a fragment of reality from the rest of the inhabited 'world'. In this sense, the image of this campaign associated with the harbour is interesting: the frame encloses a medium shot of a cheerful man wearing a sailor's hat and a striped t-shirt, surrounded by crates of fish and commercial fishermen's nets, which sit outside of the frame and which the tourist who visits the island will probably never see or smell. There is also a postcard that promotes a golf course, yet where the frame defines the limits of an image in which we only see a young woman smiling over an unusually green backdrop for a Mediterranean island in the summer. 
However, it is a different use of the postcard frame that interests us in this article: the postcard's identification with an emblem that simplifies or falsifies the actual image of the island and which is converted to denounce the negative effects of both tourism and an institutional promotion that insists on its idyllic aspects, while hiding the wounds of land development and the over-exploitation of the island's resources. In the remainder of this article, I will analyse different mechanisms of conversion that use the postcard as a material, a support or simply a portrayal model. In the first sense, we must remember the considerable history of the use of the postcard as an artistic medium, which is obviously intertwined with the different manifestations of postcard art. Additionally, in the Catalan cultural context, this artistic use of the postcard format has often been tied to a critique of a perception of the space and culture as heritage (i.e. in Perejaume or Domenec installations). The second type of subversion is related to the more subtle use of the postcard, not as a support, but rather as an imaginary framework that encapsulates a specific scenario that is presented as unique to or emblematic of a given location. I understand that the latter use of the postcard as a reference is vaguer and that its casuistry is more difficult to justify. Rather than being tied to a specific format, it relates to an embodiment of the tourist gaze described by Urry. One such example can be found in the images of the Twitter account titled, 'Humans of the Late Tourism', where, among other things, we see numerous tourists in photos or taking photos in emblematic places. In these images, the fringe of the tourist gaze is interrupted from a meta-reflexive position, often becoming comical, thanks to the portrayal of the massive or ridiculous nature of the tourist's position. Both of these techniques are used from critical perspectives in contemporary Mallorca, giving rise to images that subvert the two basic coordinates determined by the postcard image: those which allude to the island space as emblematic or idyllic; and those which concern the present-time dimension of the tourist photo.

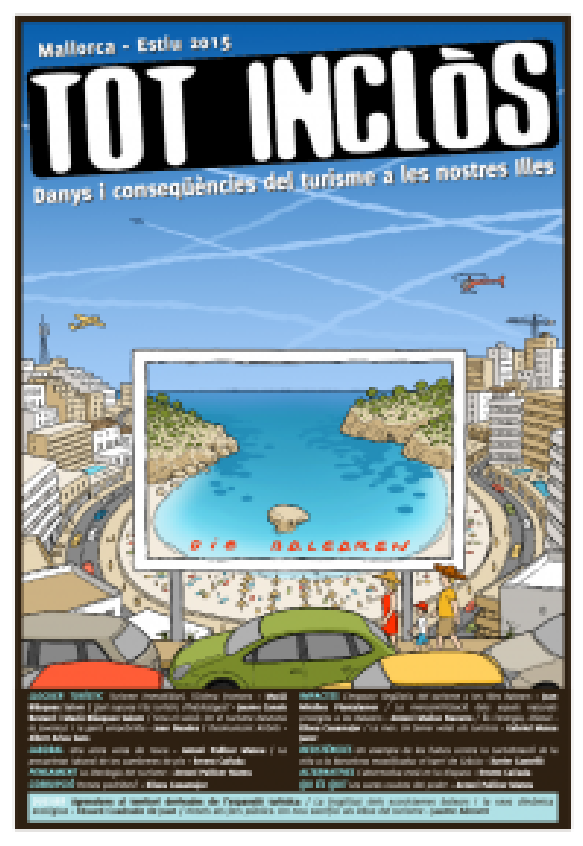

Figure 5. Cover of the 2015 issue of the magazine Tot Inclòs. Danys i conseqüències del turisme a les nostres illes. 


\section{Space portrayed: Revelation of the off-camera and counterpoint anchorage}

The space of the postcard is always limited to what its rectangular plane can contain and its symbolic function, which aims to summarise a unique gaze or experience. The subversive manifestations discussed here challenge these limits in two different senses: a) through what we could refer to as the revelation of the off camera (drawing on a cinematographic comparison); and b) through the critical use of the verbal anchorage of the iconic image. The former use can be found clearly, for example, on the cover of the first issue of the magazine Tot Inclos ('All Inclusive'), an annual publication of reports on the damages and consequences of tourism in the Balearic Islands (Figure 5).

This can also be seen more subtly in cartoonist Pere Joan's book, Memòria selectiva. Postals dibuixades de Mallorca al limit (2017) (Figures 6-7). Here, the postcard serves as a conceptual point of departure for the consideration of the memory itself as a place from which to behold the landscape. The introduction stems from a context in which the only possible postcards that continue to present a paradise place would be those that avoid the human footprint. The cartoonist's vision includes the memories of a touristic Mallorca that nevertheless precedes what has become known as the 'second implosion'. Hence, the images he offers are not postcards, but rather post-postcards that are created from memory and therefore allow for imaginative speculation and complex temporality. Their remembered past is no longer that of a nostalgic region free of tourism, but rather the past of a holiday usage that is nevertheless friendly, in the space portrayed on the postcard. Hence, all kinds of body types are depicted-as opposed to the beautiful bodies (usually women) that typically appear in postcard imagery - and the small hotels have nice, repetitious names evocative of the sun, the sea and the sky: Sol y Mar, Cel i Mar, Maricel, Vistamar, etc.
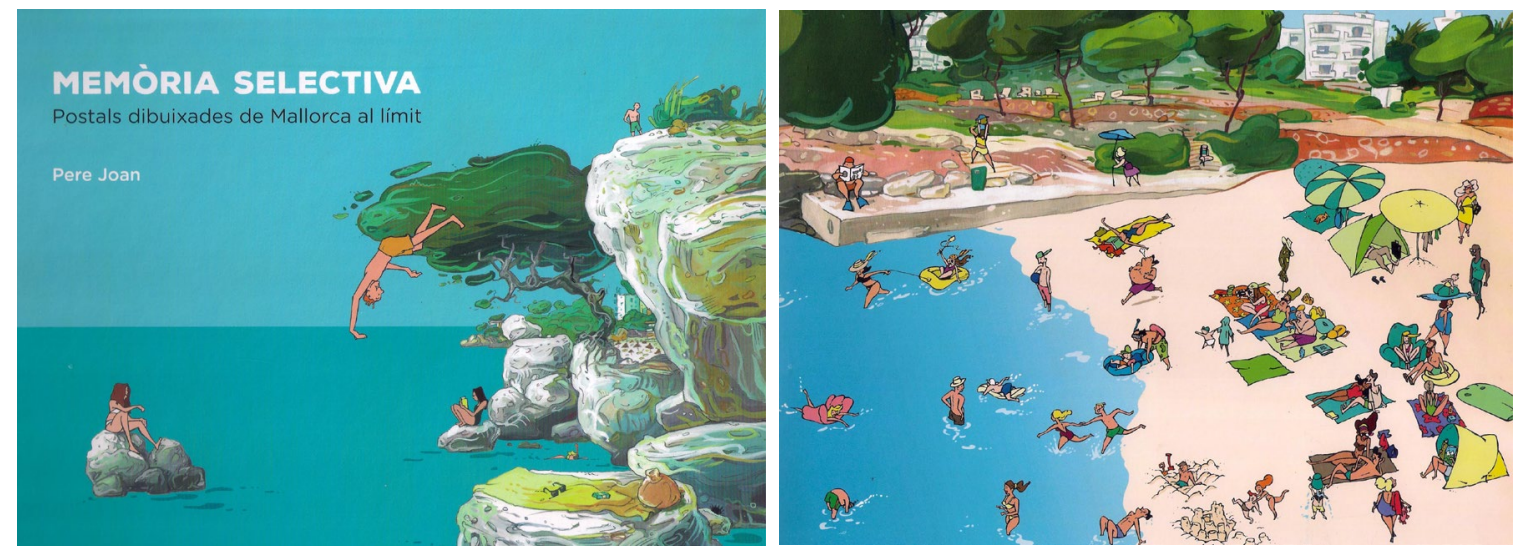

Figures 6 \& 7. Memòria selectiva, by Pere Joan (Riera, 2017).

This transcendence of what 'fits' on the postcard can also occur through the projection of two different temporalities within the framework of the photo. The Edén project by Juan Aizpitarte, associated with the 'Ciutat de vacances' choir project, plays with the limits of what the tourism gaze represents, multiplying the images portrayed on the postcard. Here, the coastal silhouettes and hotel icons of Mallorca are projected in slide shows with different overlapping images. The project is presented with the aim of juxtaposing the subjective memory with the island's tourist imaginary. It also has an odd effect, as it displays the very limitation of the postcard, its materiality and the uniqueness of its focus, which is subverted 
here. In a single glance, we see the landscape and the people who are beholding it, along with a hotel and a person who is photographing the seaside scenery. The 'Edén', or paradise, that is usually portrayed on postcards is precisely relegated to the background of the image, behind the lit-up sign of a hotel that has effectively been given the name 'Edén' (Figure 8).

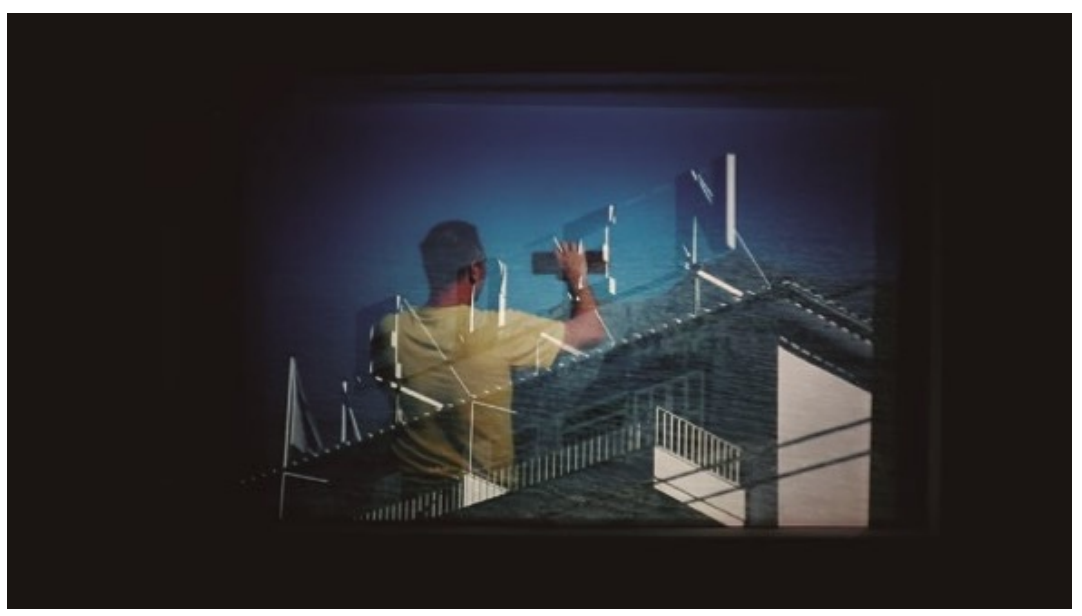

Figure 8. Image of 'Edén', by Juan Aizpitarte.

The two proposals described above expand the limits of the space portrayed on the postcard or on the tourist photo, as in the second case. From the strict format of the postcard, we must additionally cite the series designed by Mariona Obrador under the title, 'Mallorca Paradise: The Dump of the European Shit'. This is a postcard series marked on the back side with a logo that displays the image of a palm tree and a local peasant farmer woman dressed in traditional Mallorcan garb. Hence, the image of the folkloric and tropical-island aspects come together in a new version of characterisation of the island that Baldacchino (2008) dubs with the phrase "small and tropical as topical." The face of the postcard features photos of sexual tourism and drunkenness, which were taken from a Google search (Figure 9).
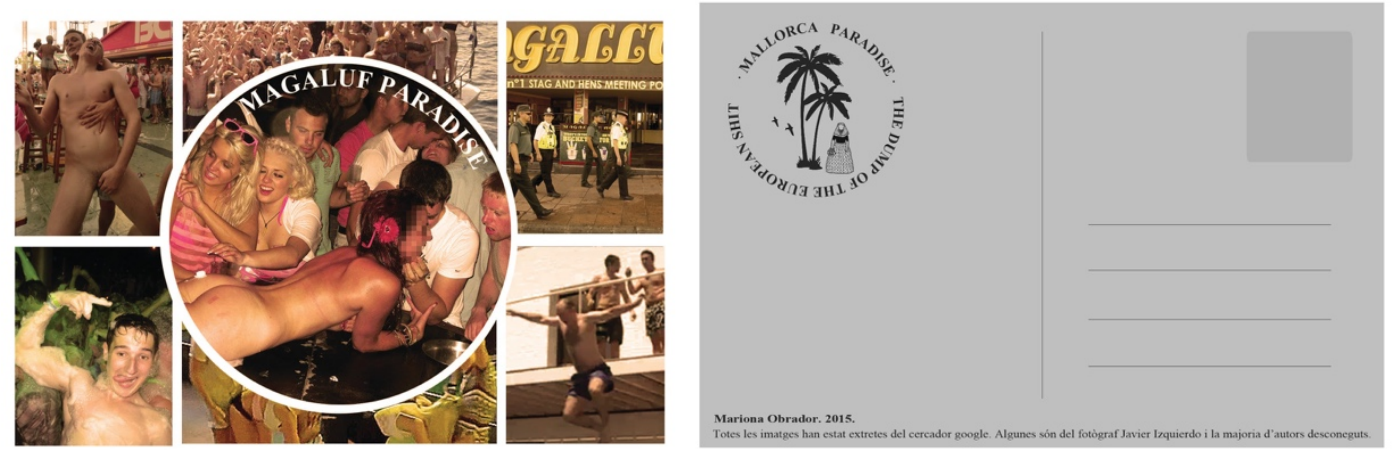

Figure 9. Mariona Obrador. 'Mallorca Paradise' (2015).

In this example, the off-camera completely replaces what 'fits' on the conventional tourist postcard. Nevertheless, it is true that the tourist postcard market of Mallorca in fact includes a broad array of sexual and scatological proposals. The 'Mallorca Souvenir' (2007) project by Miquel Àngel Joan (whose penname is 'Llonovoy', which phonetically translates to 'I'm not going') also includes a series of actual postcards that have been modified to underscore the pollution - in the form of cigarette butts and ashes - that accumulates on the picture-perfect beaches displayed on the postcard (Figure 10). These postcards form part of 
the project 'Cimentiments o no m'asfaltis el respecte, a play on words that roughly translates to 'Cement-iments or don't asphaltingly disrespect me'.

Figure 10. 'Mallorca Souvenir' postcards, by Miquel Àngel Joan (Llonovoy).
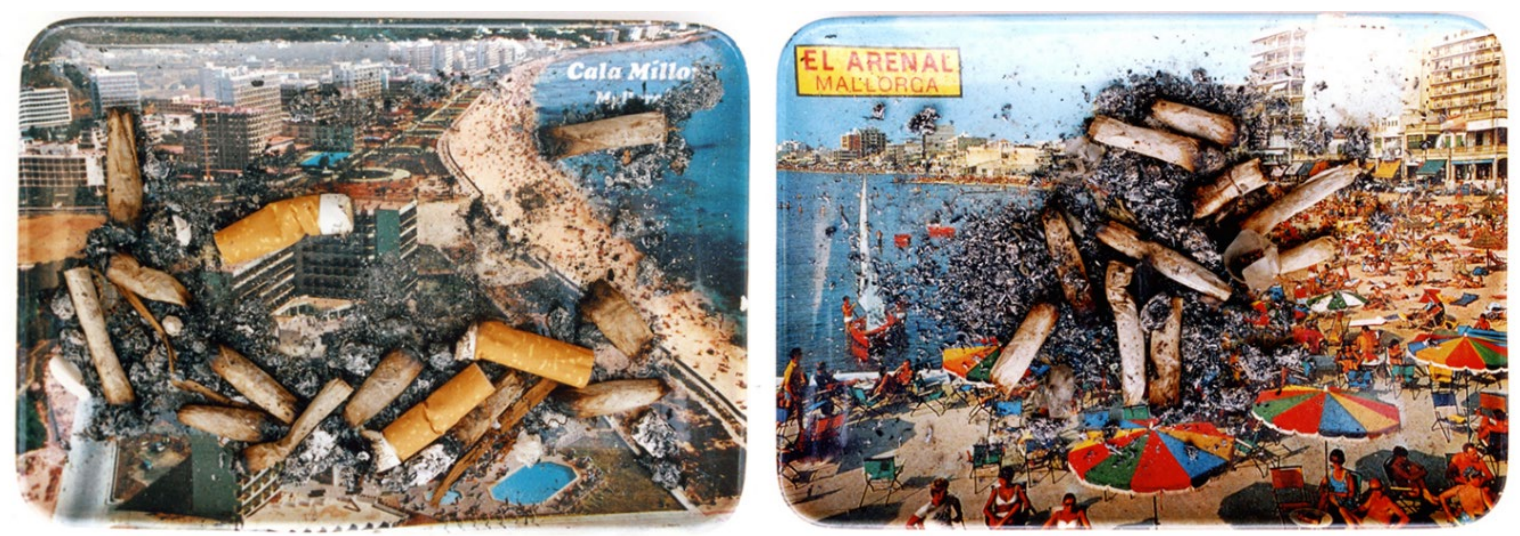

\section{Cales per no trepitjar}

Top 4 beaches of the island

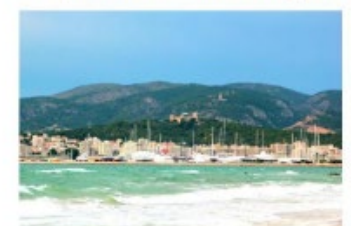

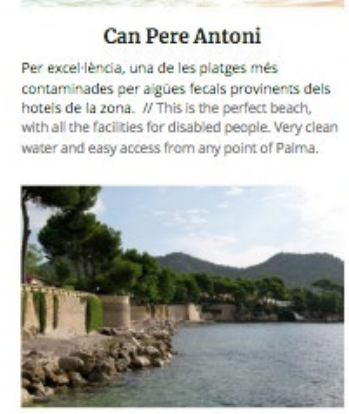

Costa dels Pins

Olor constant de depuradora i amb la preséncia visitar la piscina "privada" d'en Pedrol. Ramire "II One of the favourite places of famous and

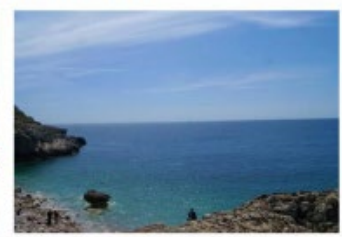

Dic de l'Oest

sovint plena de brossa i plastics. Més enlla dees Sovint plena de brossa i plasstics. Més enllà deis
tradicional's tampons i compreses, shi nan tradicionals tampons i compreses, shi han
arribat a trobar fins i tot pneumatics. /IA hidden spot in palma. From there you can see traditional

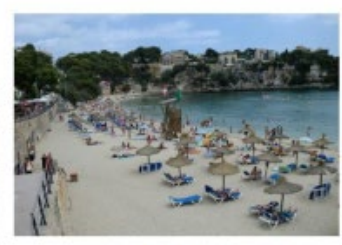

Porto Cristo

Aigües tèrboles, tems i taques đolil a dojo. Fragancia de benzina per les tarques i iors que hi van passant. $/ /$ A good beach where you can
go with children. Ideal place for snorkeling and

Figure 11. Mallorca Guide. Foc i Fum, 2018.

For the moment, we see the way all these proposals are shaped subversively, in the strictest sense of the word. In most cases, a tourist hypotext is used more or less intensely to subvert the meaning. Hence, these postcards are at once critical and dependent on a preestablished model, the limits or meaning of which have been modified. This is also the case of the Mallorca Guide that was created by the comical portal Foc i Fum for 2018, featuring a presentation almost identical to that of the institutional promotion guides (Figure 11). On the cover, a single minor detail marks the subversion of the guidebook: the difference in the price of the publication in the islands vs. its price on mainland Spain, with an inversion of the typical added price of certain products in island regions. The content is all bilingual, in Catalan and English, and the play on meaning is often manifest in the blatant discrepancy between 
the Catalan text and its translation, the latter embellishing the meaning of what is stated in the original text. This occurs, for example, in the description of the island beaches that the locals attempt to avoid at all costs - urban beaches that in many cases are not particularly clean-and which are recommended to tourists in English; as well as the report entitled, 'Consells per fer balconing' (literally 'Balconing Advice'), which is translated in the publication for tourists as 'How to Avoid Balconing'.

The most important aspect of this comical proposal is its double reception. The model reader appears as a receiver who is capable of interpreting two different discourses at once: the one that targets him/her as a resident and the one that apparently targets a 'naïve' and 'gullible' tourist. We shall see later in this article that this duplicity is important in the configuration of a resistant position. This parodical guide is associated with the second strategy, which entails the subversion of the space that fits in the image; and the postcard imagery that I have introduced earlier is related to the discursive anchorage of tourism icons. I understand the concept of anchorage in the sense attributed to the term by Roland Barthes (1964): as a textual strategy that pinpoints a specific meaning within an otherwise ambiguous image. The text of the postcard usually appears on its back side, where the visitor writes, sending greetings as a memory of 'having been there'. In contemporary Mallorcan pieces, however, artists play with the texts that accompany the postcards, placing meaning in a different frame of action. The most obvious case of this can be found in 'Imatges turístiques. Aproximacions històriques' (2017), where Marina Planas creates an audiovisual that combines images from the photographic archive of her grandfather, Josep Planas Montanyà. Such images document the scenarios of the original landscape and tourist expansion in Mallorca. The images are counterpointed by the video's audio track, which combines songs that were used to promote tourism and became typical in the Spain of the 1960s, describing Mallorca as a paradise - with soft music in the background and a suggestive voice-, with voice cuts reporting the news about the excessive binges of the tourists on the island: the phenomenon known as balconing, drug abuse and sexual tourism. The contrast is multiple here. The texts contrast with one another, while at the same time almost contentiously anchoring the meaning of the images. In the case of the promotional texts, the postcards of the mid- $20^{\text {th }}$ century primarily displayed tourism establishments, as opposed to the idyllic landscapes that would later occupy the imagery of the island, falsifying its current highly-developed urban nature. Secondly, in Planas' montage, the contrast is one of time: the tourism of wild drunkenness is juxtaposed with the image of a more peaceful tourism of the past, which, as is the case of the Postals dibuixades by Pere Joan, become a sort of nostalgic past set against an uninhabitable present.

Esther Olondriz has also used the postcards of the Planas collection as her base, intervening on them to show the other face of the tourist image in her project, 'Paisajes lindos' (Figure 12). 


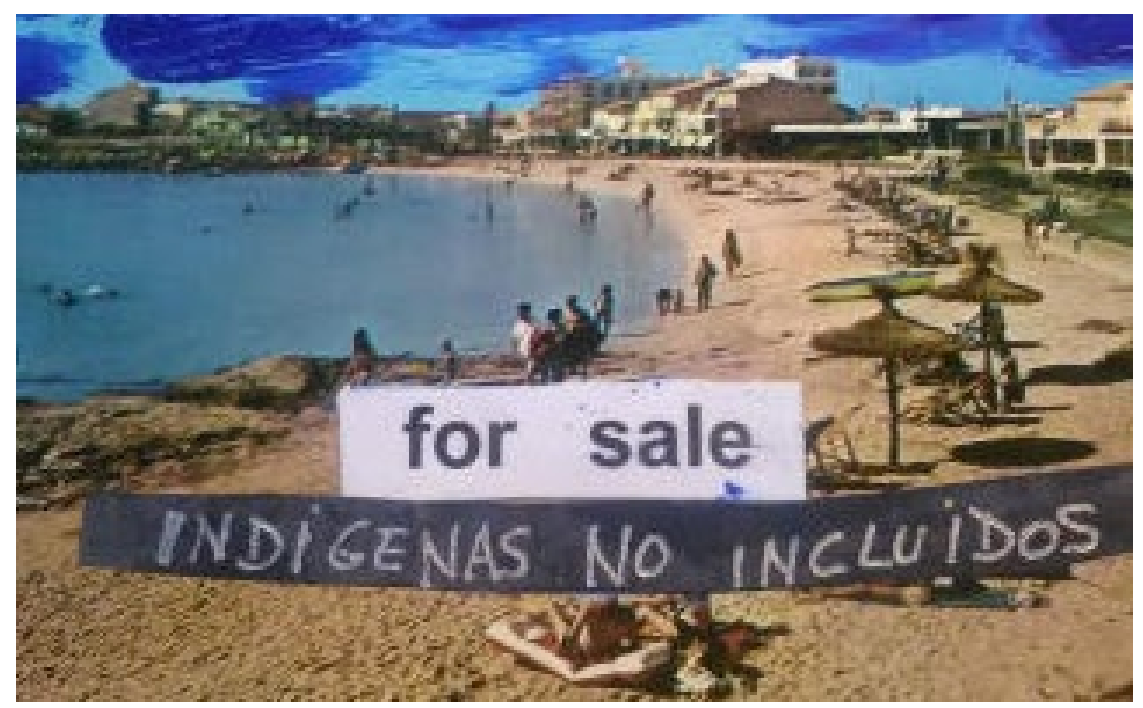

Figure 12. Esther Olondriz 'Paisajes lindos' (2017).

Our interest in the work of Planas and Olondriz also resides in the fact that they create archival material that remains on the fringes of what the institutions feel could ever come to be heritage. Photography continues to occupy a small space in historic archives. The photo archive kept by Casa Planas - currently an art centre - is important heritage for the history of the island and embodies an uncomfortable past that displays the evolution of the tourist exploitation of their region. This archive recently inspired a documentary on the function of Casa Planas' postcard photography, titled, Postcards and memories, sol y turismo en Mallorca. In different media, Marina Planas has defended the historic need for this archive as a memory from which to project a future. The archive, according to Foucault (1969, p. 23), marks the limits of what is said. What remains outside of the archive tends not to remain; it tends not to be pertinent in the present, where a memory is affirmed as such. Recovering it also means generating new spaces from which to imagine a different future.

We will soon return to the matter of time as regards these products that are critical of the tourist imagination, and at the end of this article, we will explore the new agency spaces that they are generating. Beforehand, I must mention one last work of subversive anchorage of the tourist image by Neus Marroig in the project, 'Imatge pública' (2017). Here, despite what the title of the proposal (literally, 'Public Image') might seem to insinuate, this audiovisual about Palma does not include any visual imagery at all. In the face of the overexposure of the island space to tourism, the city is portrayed with no iconography, but rather through the black and white lettering of the texts that have proclaimed its beauty and which contrast with the soundtrack of the current city, from the silent waves of the morning as the island awakens to the day, to the chaos of the voices, music and vehicles of the nighttime party scene. The tourist gaze fades to black, giving rise to its discourses in other media. Once again, the tourist scene appears, pierced by coexisting discourses; however, such discourses do not appear in the stereotypical portrayals of the destination for leisure and relaxation.

\section{Calm and timelessness: Consequences of the 'What happens in $X$ remains in $X$ ' effect}

By definition, the temporality of the tourist postcard is limited. It aspires to create a memory, yet from the atemporality of its frozen image, which neither displays history nor describes 
what Lessing would call the most 'fertile' moment (1989 [1766]) of a story that will always be shown on the back side of the postcard, if it is given any space at all. Urry identified a triple time perception in the tourist experience, which would determine its contemplation. The first perception is anticipation, where the images and discourses have shaped a preconception of the destination to be visited. The second is a place of liminality typical of the tourist stay, determined by the sensation of being 'outside of space and time', in an extraordinary moment where the norms of coexistence and behaviour of ordinary time are inoperative. Finally, the image becomes a catalyst of the memory of a past experience. The tourist postcard is a sort of emblem of this ahistorical triple temporality connected with a model of portrayal of the destination. Whether the images shown are idyllic landscapes, folkloric characters or erotic scenes, the postcard represents both what the tourist was expecting to find and the aspect of his /her experience that he/she wishes to show to others. Verena Winiwiarter (2008) also identifies a symbolic reproduction function of national ideology on postcards. According to Casilda Cabrerizo, Granalí Rodríguez and Isabel Rodríguez, "the postcard is the created image of the tourist site that has embedded itself in the social imaginary" (2011, p. 192). Hence, it generates a hetero-image of the tourist enclave that at the same time affects the resident's conception of his/her own home environment or identity. Carol Crawshaw and John Urry identify two types of reactions among the local inhabitants in the face of this powerful tourist gaze, which they characterise as panoptic, drawing inspiration from Foucault (1997, p. 179):

Moreover, we can see something analogous to the processes of interiorization as produced by the panopticon. Those living in tourist 'honey-pots' may believe that they are always being gazed upon, even if they are not in fact visible. So locals may not venture out, or they may do so only in ways appropriate to the gaze. Thus, the gaze may be interiorised, creating a universal visibility which serves a meticulous, rigorous, powerful eye. Locals may seek to restrict the length of the tourist season, to preserve part of the year 'out of season-out of sight' of the eye and the lens.

Elvira Pulitano (2016, p. 152) insists on this effect of the tourist gaze in the Caribbean islands, which is also determined by colonialist rhetoric: "Not only are natives objectified and exoticized in the glossy brochures of the tourist industry; they are expected to attend to all the 'needs and whims' of the tourist, performing the role of the happy natives inhabiting paradise islands." More still: I would add that this "appropriate way of behaving" that the tourist gaze seeks can come to convert their imposture into habitus, modifying the resident's conception of his/her own identity. This issue has already been studied in relation to the portrayals of the city of Palma (Picornell, 2010; Moyà, 2015, 2017). In such depictions, the projected image of the peace and quiet of Mallorca as a tourist destination for a pleasant rest contrasts with the reality of a growing city that is also a place of transit; in other words, the main gateway through which visitors access the rest of the island territory. This portrayal of the 'calm' city that can be found in countless visitor guides ends up crossing over to the image that the residents themselves project on the city's identity. In other words, in the chronicles of different eras, that image is a place oriented to quietude, suggesting that it is timeless and incapable of change. This image does not serve solely for the context of Mallorca. Rather, as Brian E. M. King (1997, p. 1-5) explains, it determines the configuration of the myth of the 
paradise island, which prevails in the construction of contemporary tourist markets (Martín de la Rosa, 2003).

This extraordinary and timeless liminal state of the island is hence for both visitors and residents a denial of coevalness similar to what Johannes Fabian (1983, p. 31) identifies in ethnographic tales; in other words, a persistent tendency to place the reference-which in his analysis is the object of study of anthropology - in a time other than the present. In the case of island tourism, the alteration of time would not (always) be determined by an idea of delay in an evolutionary time line, but rather (also) by a stillness that makes the scenario ideal for the extraordinary, while at the same time distancing it from the prospect of imagining possible futures that might serve as a place to escape from this panoptic and heterotopic leisure present, like the jails described by Foucault. In terms of tourism, we could ironically redefine Fabian's denial of coevalness as the 'what happens in X stays in X' effect, which appears on tourist postcards and t-shirts around the world. The tourist present is not rooted in a past, yet it does not have any future transcendence, either: it is simply a current time.

In the cases studied here on contemporary Mallorca, this timelessness is not subverted by appealing to a pre-tourism past, but rather by evoking a form of friendlier tourism that existed before the sense of saturation. When we see a future projection of the island space in critical discourses that speak out against the tourist model, such projection is usually based on its dystopic image. That image, which is associated with the over-exploitation of the island, has a certain literary tradition. In Andrea Victrix (1976), Llorenç Villalonga visualises the Palma of 2050 as an enormous resort called Turclub. In his L'infern de l'illa (2002), Pere Rosselló imagines the return of painter and writer Santiago Rusiñol-author of the book L'illa de la calma (translated into English as 'The Island of Calm') (1913) —, where the artist arrives to a huge ensaïmada-shaped airport from which he can never escape and which becomes a sarcastic Dantesque inferno. A similar image - that of the island that has become an asphalt ensaïmada-appears in 2005 in one of the posters of an exhibition sponsored by the association known as Ateneu Llibertari Estel Negre (Figure 12).

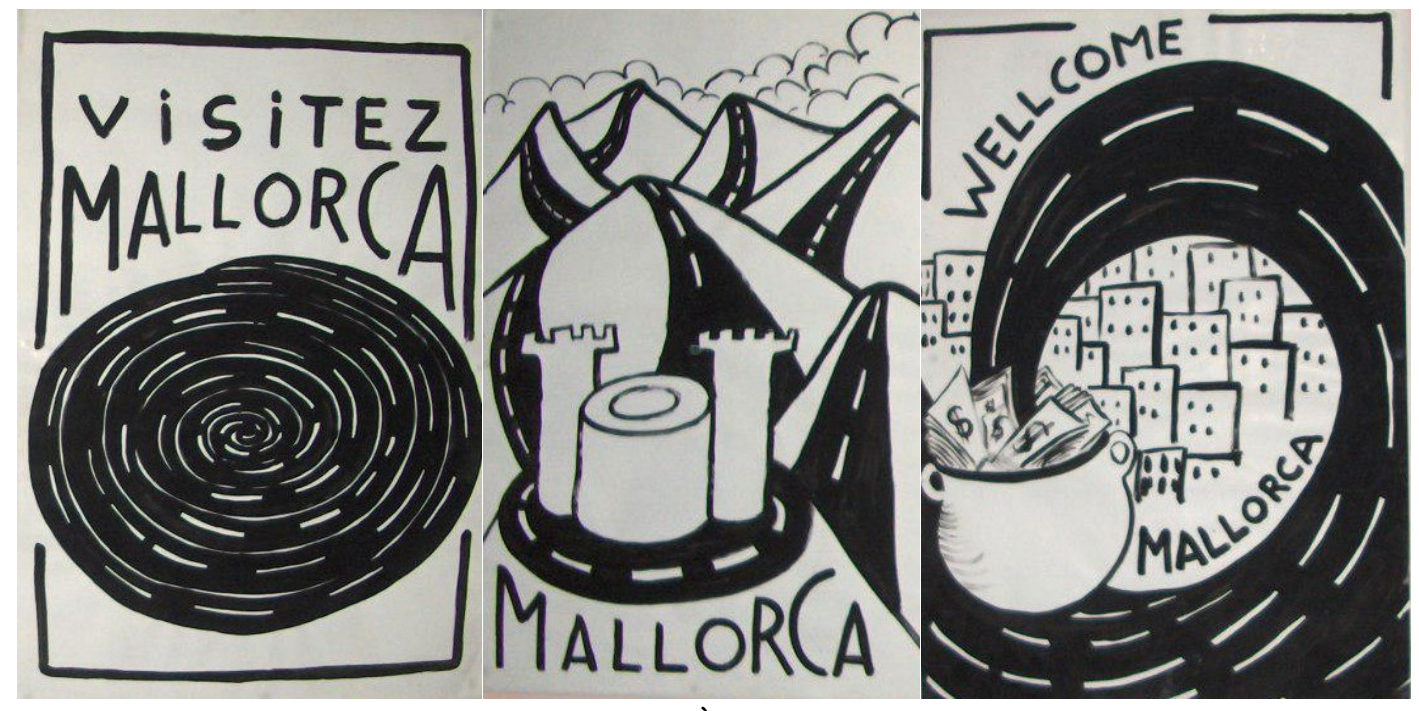

Figure 12. Judit Bacardit and Miquel Àngel Joan (Llonovoy). Exhibition in the cultural association known as 'Estel Negre', December 2005. 
The dystopic image of an over-saturated and over-developed island is frequent in the ecologist imaginary of Mallorca, which is often connected with the portrayal of the geographic silhouette of the island. The postcard of the 'Souvenirs' series by Miquel Àngel Joan displays a damaged and trampled tourist map (Figure 13).

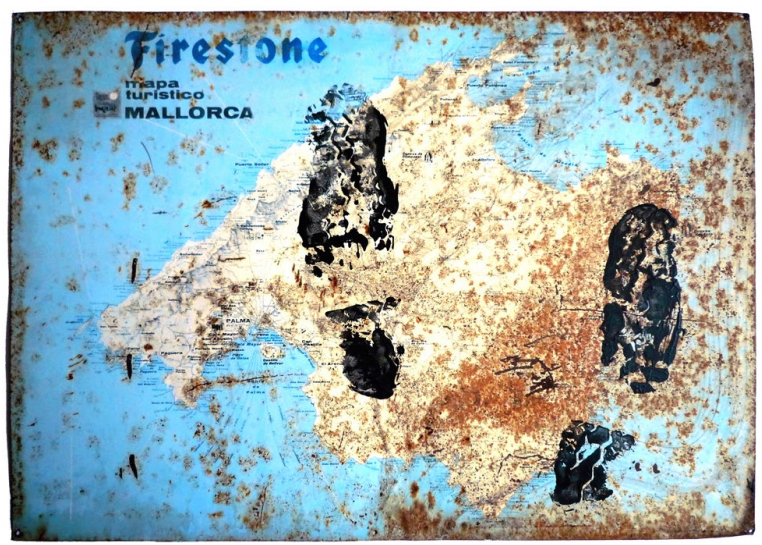

Figure 13. Postcard of the 'Mallorca Souvenirs' project, by Miquel Àngel Juan (Llonovoy).

More often, the apocalyptic map of the island offers a sharp contrast to both the typical postcard model that portrays the silhouette of Mallorca and the tourist promotion maps that display the attractions as beautiful enclaves in an environment featuring the green of nature, the yellow of the sun and the blue of the sea. In Culture and Imperialism (1993), Edward Said insists on the need to understand the aspect of geography and its portrayal as a site of combat in contexts of resistance. Said writes: "Just as none of us is outside or beyond geography, none of us is completely free from the struggle over geography. That struggle is complex and interesting because it is not only about soldiers and cannons but also about ideas, about forms, about images and imaginings" (1993, p. 6). The act of geographic violence, which is imposed by imperialism, according to Said's study, would only revert through a reinstatement of the "geographic identity." This reversion would have to take place on the very plane of the combat suggested by Said: that of images and imaginaries. In our field, which is also conditioned by the economic and political powers' imposition on the space, there are countless posters that draw on the silhouette of the island of Mallorca to revert the postcard image. They often show the island space completely developed and full of motorways, roads and hotels.

One of the images of the 'Qui estima Mallorca no la destrueix' campaign (Figures 1416) reads: "Year 2025 AD. The entire island of Mallorca is crossed by motorways, highways, junctions and high-speed roads, as a result of the Highway Plan of 2004. The entire island? Not yet. A small village still resists, though the excavators are about to come in and finish the plan” (Figure 15). 


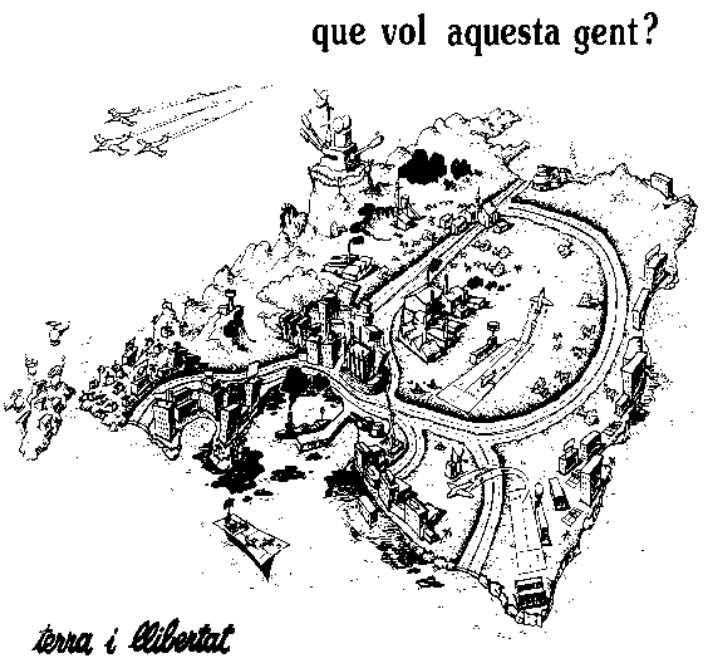

Aturem el Pla de carreteres

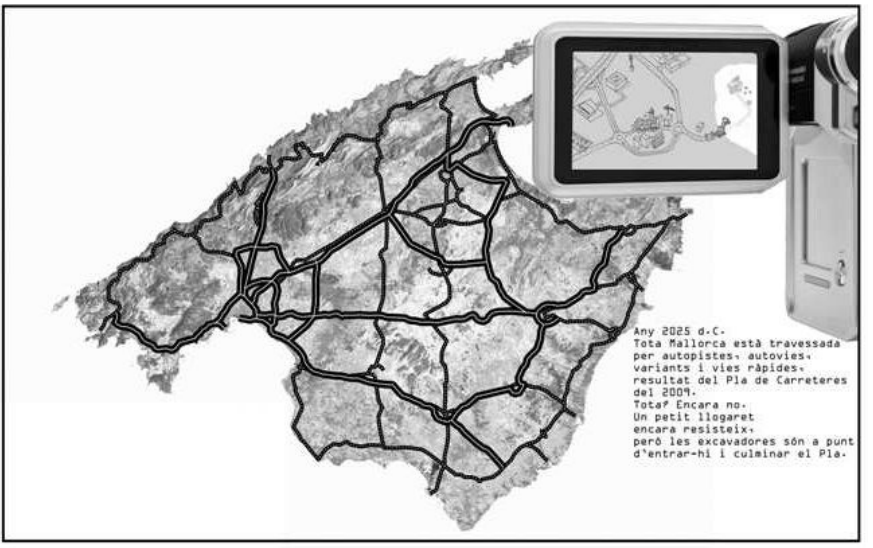

Qui estima Mallorca no la destrueix

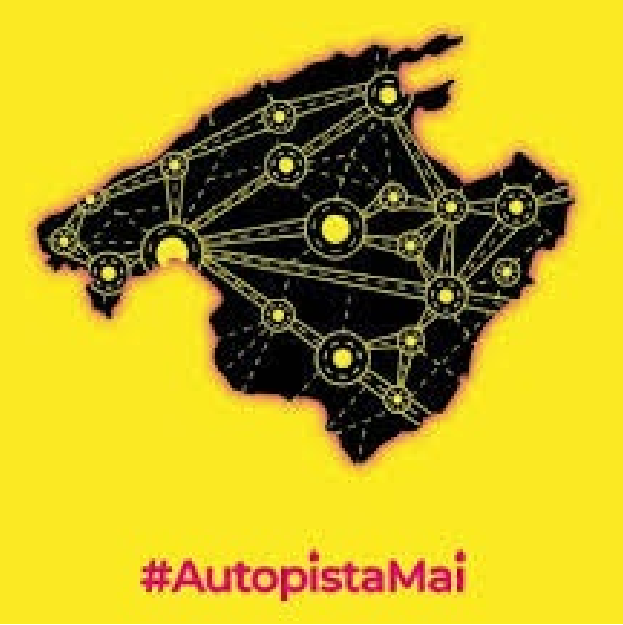

Figures 14, 15, \& 16. Images from the campaign 'Qui estima Mallorca no la destrueix' (roughly, 'If you love Mallorca, you won't destroy it') (2004) and 'Autopista mai' ('Motorway never') (2018).

The intertextual irony with a nod to the Asterix comic series sets the ecologist action in a place of resistance. The Terraferida group, which was created in 2015, draws on similar imagery in its critique, which aims to create a counter-image to the 'idyllic' picture put forth by institutional promotion. The heart of its logotype is the enlarged image of a real roundabout over the entire island (Figure 17). To speak out against the increase in tourist accommodations, the whole of the island is filled with the logos of actual Airbnb locations (Figure 18). The data portrayed are real. Their synecdochic projection on all the land of the island has a dystopic effect. 


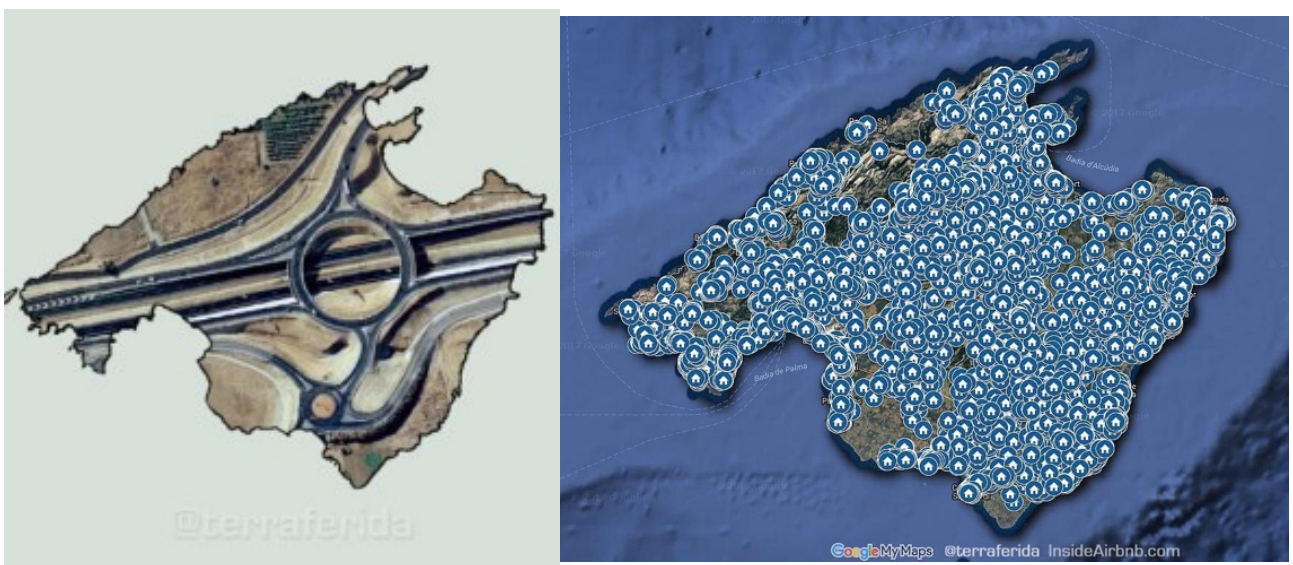

Figures $17 \&$ 18. Logo of the group Terraferida and Google Maps image with the lodging sites offered by Airbnb.
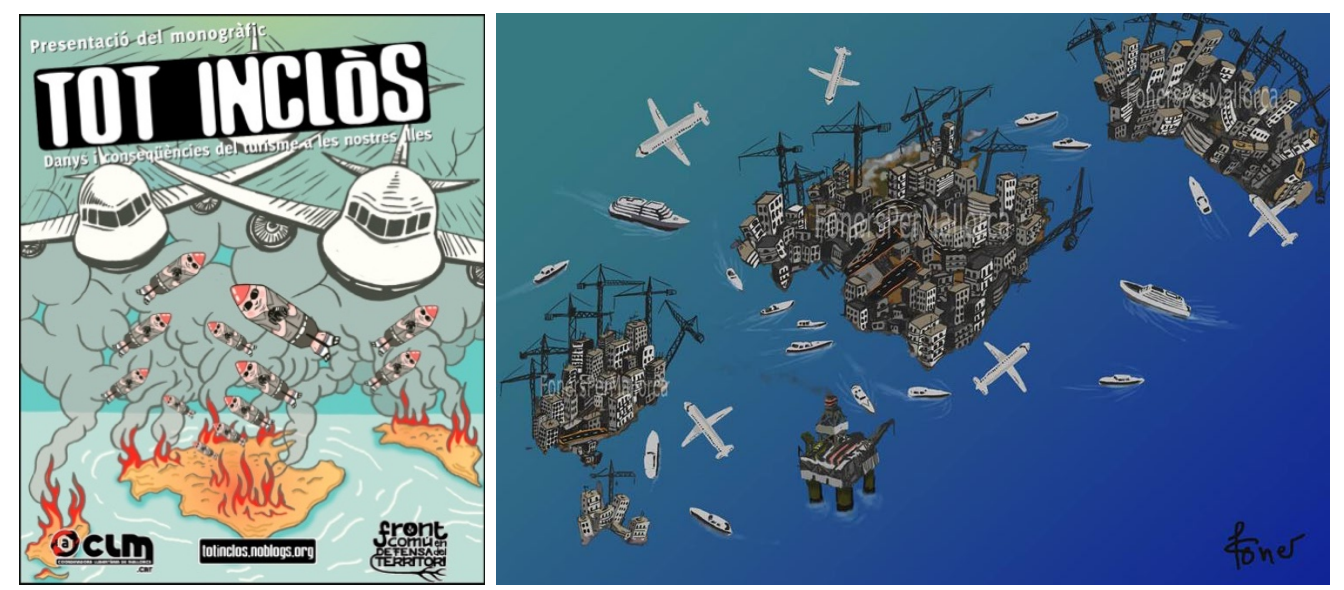

Figures $19 \& 20$. Cover of the magazine Tot Inclos and image disseminated through the internet by Foner (see 'Foners per Mallorca' on Facebook).
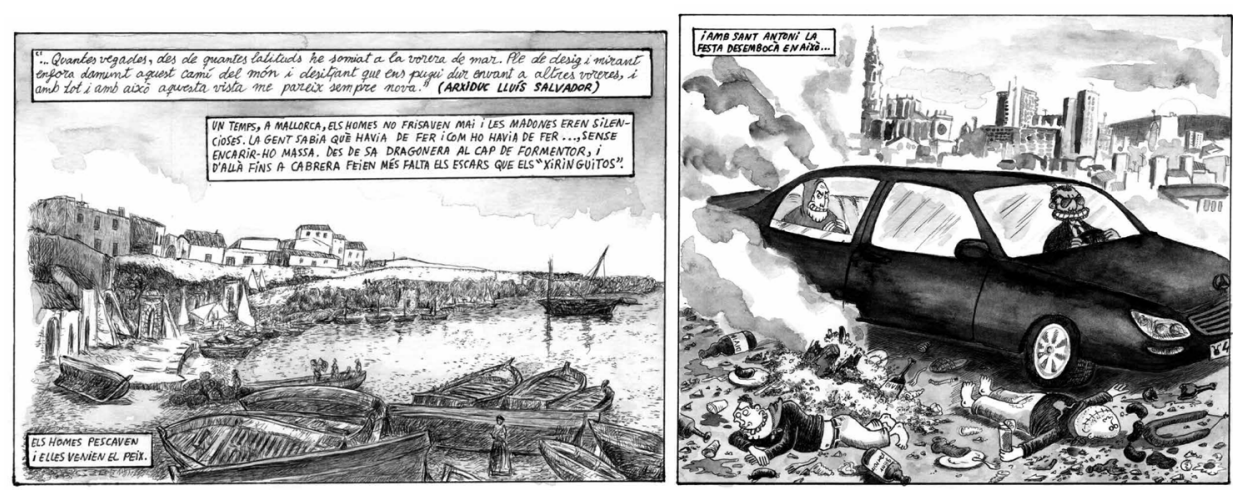

Figures $21 \& 22$. Images of the comic Els darrers dies de l'imperi mallorquí (2014) by Toni Planisi and Xisco Fuster.

These sorts of portrayals also appear in the imagery of some Mallorcan underground comics of today and specifically in the series Un infern a Mallorca. El declivi de l'imperi mallorquí (roughly, 'An Inferno in Mallorca: The Fall of the Mallorcan Empire') and Els darrers dies de l'imperi mallorquí ('The Last Days of the Mallorcan Empire'), an uchronic and satirical tale of the evolution of the island and its traditional references (Colom-Montero, 2019) (Figures 23- 
24). In the first of these publications, the postcard image sustained by the paradigmatic descriptions of the 'island of calm' described by Santiago Rusiñol, Miguel de Unamuno and Miquel dels Sants Oliver is juxtaposed with a world of chaos, corruption and terrorism. The images of the island appear again, filled with buildings that virtually appear to bulge out of the island's limited territory.
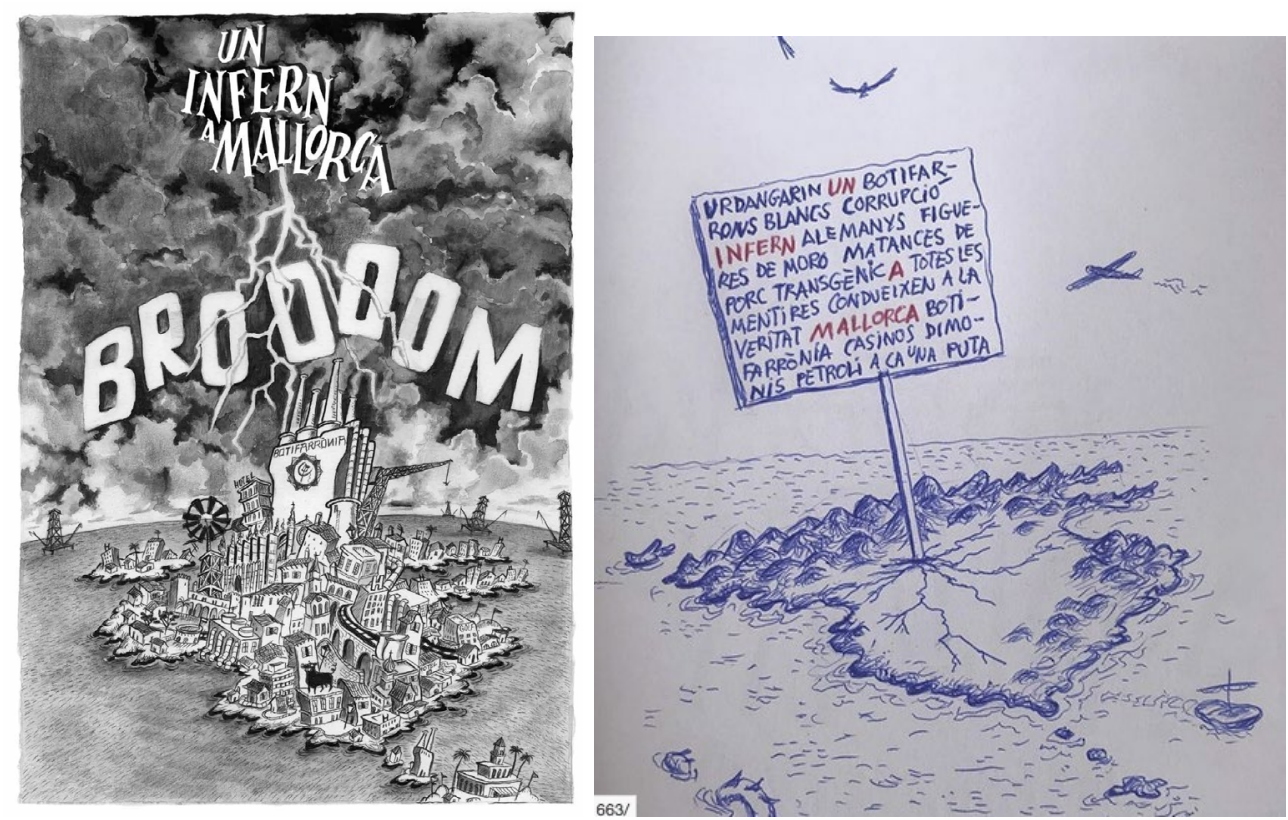

Figures 23 \& 24. Back cover and promotional image of Un infern a l'illa (2018), by Toni Planisi and Xisco Fuster.

The apocalyptic image aims to alert the reader to the future consequences of the current model of tourism growth, if sustained. Hence, the island is presented completely vulnerable, as a place that is too small to hold so much asphalt. There is absolutely no use of the beauty of any aspects that have remained intact to state that it is worth being conserved and restored, as though depicting such beauty would in itself constitute a threat in a place where the very advertisement of a 'paradise' has led to its destruction.

\section{Final thoughts on an islander agency}

The images analysed thus far are re-inscriptions in the sense that Said (1996 [1992], p. 27) attributes to the term; in other words, interventions that cannot avoid the 'tragedy' that he identifies in all acts of resistance, as the native culture must work to recover forms already established by the agent of (touristic) power. Nevertheless, this interfered position is not necessarily always tragic. In rereading Fanon, Homi Bhabha (1994) identifies in the ambivalence of cultural resistance an ability to display the limitations of power through their performance. David Jeffers (2008) offers a revision of cultural resistance as a means of transforming the structures and cultures that sustain the power, the tales and images of which affect the construction of the subjects and their actions. Viewed in this light, as an act of resistance, the re-inscription of the tourist image of the island is not (only) politically active in what it denounces, but (above all) in its capacity to generate new political agencies. 
As we have seen, in Memoria selectiva, Pere Joan aims to recall a past in which the postcards depicting Mallorca included people: "Now, shamed by the over-development and exploitation of the environment, all human remains have been eliminated from postcards. No more highways, no more hotels, an unpolluted world free of people" (2017, p. 5; translation our own). This absence of people presents an empty destination occupied by no-one; not even the resident that once represented the folkloric identity on certain postcards in the past. The forms of subversion of the tourist gaze analysed thus far also avoid the portrayal of the resident from the perspective of his/her image. Instead, they convert this population into an agency capable of generating other images over 'its' territory. That agency goes beyond the objectivization of the resident in both the tourist imagery and the configuration of a knowledge of the island subject that Baldacchino (2018) has explored. However, it is constructed from a position of resistance and hence a position necessarily vicarious to the model of portrayal against which it speaks out. In fact, the few times that island residents appear depicted in the island imagery, they are associated with the folkloric referent as a place of identification and cultural resistance. The peasant farmer dressed in traditional garb is shown in two contradictory positions-even in productions by a single creator: that of the victim and that of the armed activist (Figures 25-28).
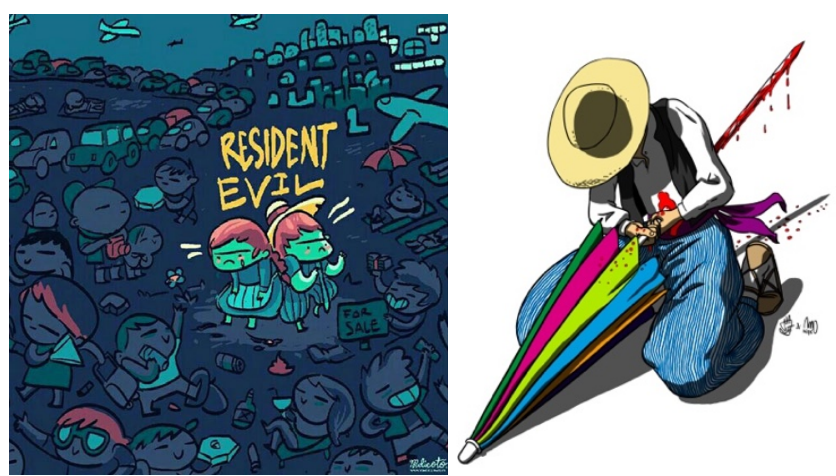

Figures 25 \& 26. 'Resident Evil', by the design company Melicotó and illustration by Juanito Comicartor.
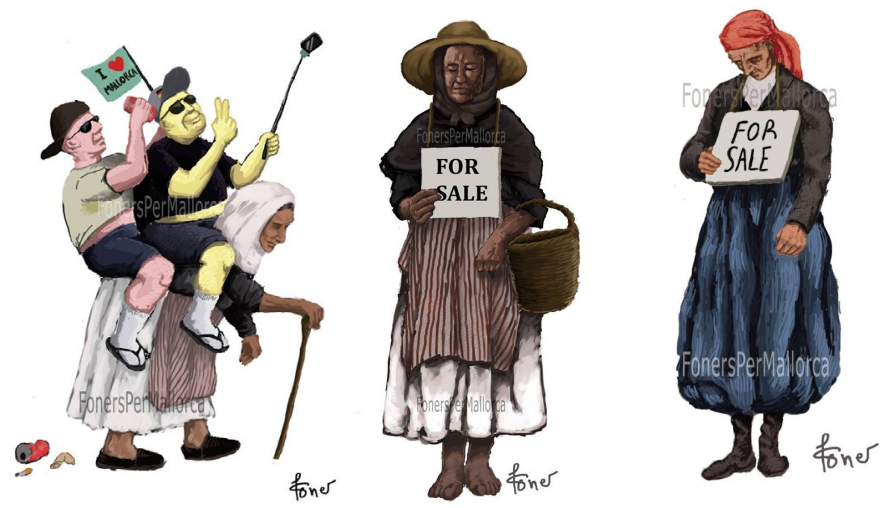

Figure 27. Illustrations by Foners (Foners per Mallorca Facebook web). 

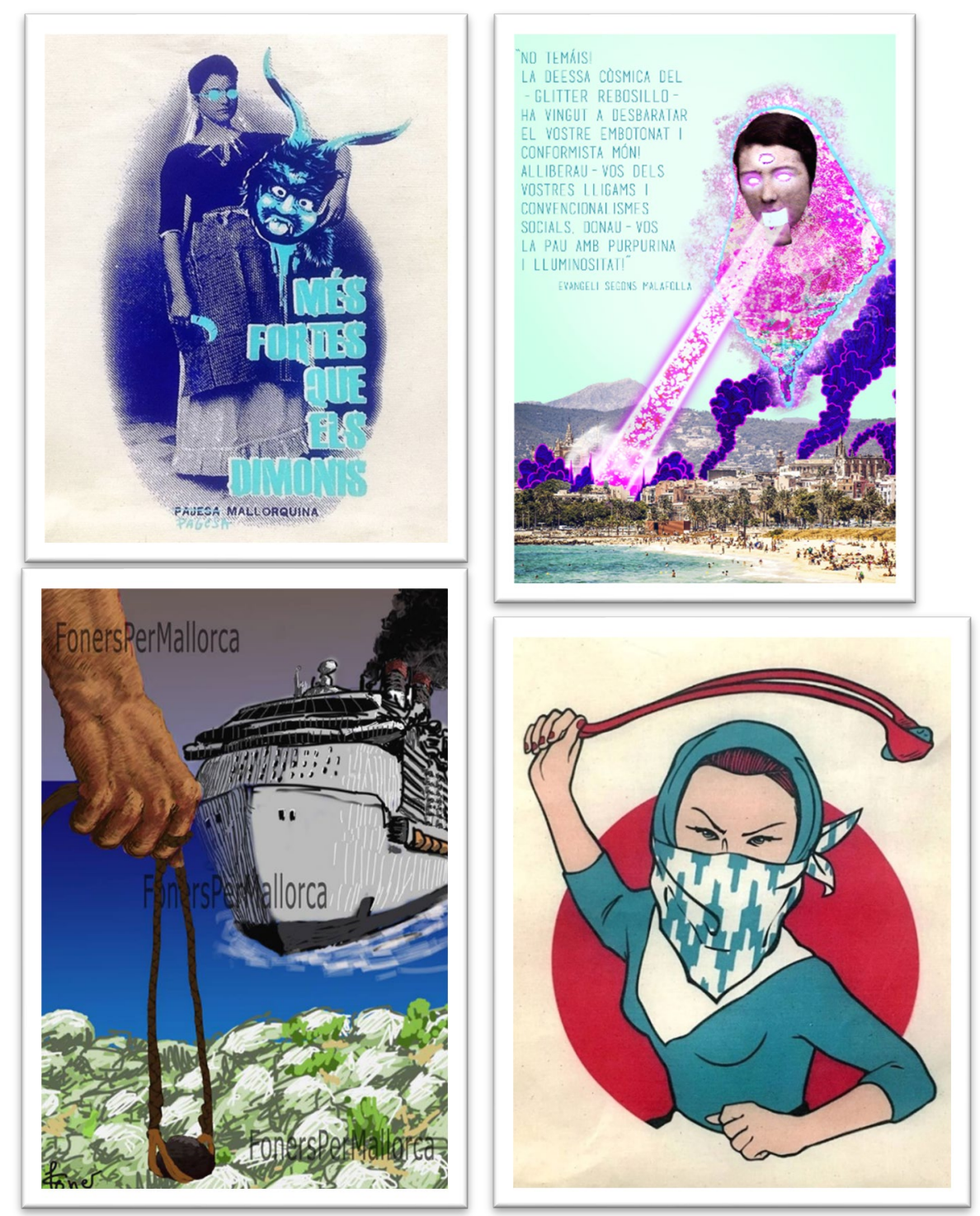

Figure 28. Postcards by Malafolla and image by Foners per Mallorca.

In Mallorca, the acceptance of the impossibility of generating non-resistant agencies and images is linked to the beginning of the formation of an identity discourse on the hybrid nature of the island. The island is presented as a mixed place, historically marked by the constant transit of invaders and colonisers, the aggregate of substrates that have led the island identity to find itself in the quandary of connecting itself to certain roots or routes, as Baldacchino (2018) also asserts. This revision of Mediterranean insularity as a place to generate new and non-essentialist political agency and identity models somewhat moves away from the defence of the enriching confluence between cultures in a shared sea, as proposed by Franco Cassano (2005 [1996]) in his theory on the south. Given the massive presence of tourists, the encounter and the journey do not always take on positive tones, more closely resembling a place of conflict, battle, resistance and inequality, as Luisa Pèrcopo (2011) has identified in the Mediterranean islands. Nevertheless, in a place as conditioned by tourism as today's Mallorca, the colonialism that Pèrcopo cites in north-south relations is even more complex, as it involves the enrichment of many islanders-some of the world's most important hotel groups and tour operators (Melià, Iberostar, Riu, Barceló, Globalia) that 
exploit other 'souths' are headquartered in Mallorca and their CEOs are listed in the Spanish Forbes ranking.

\section{Conclusions}

Throughout this article, we have seen the formation of a complex imaginary that subverts the tourist gaze presented emblematically in the postcard image, by changing the space that it can portray and cancelling out the calm present offered as an extraordinary destination for the visitor. We have identified at least two mechanisms of subversion that revise the coordinates of space and time presented in the tourist gaze, in works from different fields, including those of activism, politics, art and culture, which at times come together with a shared objective. The examples presented are a mere sample of many others that could also be analysed from other enriching perspectives, for example, in connection with political or historical processes. Here I was interested in simply devising an initial analysis of the forms of subversion that would serve as an indicator of the generation of a new discourse on tourism and the island reality. The challenge to be faced in the upcoming decades by the resistance agencies presented here is perhaps related to the possibility of visualising a space and a future not saturated by the images of tourism, yet which at the same time assumes tourism's complex and contradictory presence as part of an idea of progress; a space that we can contribute to reinventing, from the context of our Mediterranean island, half-way between Europe and Africa.

\section{References}

Andrews, H. (2011). Porkin' Pig goes to Magaluf. Journal of Material Culture, 16(2), 151170. https://doi.org/10.1177/1359183511402872

Anywar, G. (2017). Sensing precarity in an overheating world: A case study of tourism in Mallorca (Master's Thesis, Leiden University, Leiden, Netherlands). Retrieved from https://openaccess.leidenuniv.nl/handle/1887/56846

Bhabha, H. (1994). The location of culture. London: Routledge.

Baldacchino, G. (2008). Studying islands: On whose terms? Some epistemological and methodological challenges to the pursuit of island studies. Island Studies Journal, 3(1), 37-56.

Banks, M. (2007). Using visual data in qualitative research. Thousand Oaks: SAGE.

Barthes, R. (1964). Réthorique de l'image. Communications, 4, 40-51.

Black, A. (1996). Negotiating the tourist gaze: The example of Malta. In J. Boissevain (Ed.). Coping with tourists: European reactions to mass tourism (pp. 112-142). Providence \& Oxford: Berghahn.

Blanco-Robero, A., Blázquez-Salom, M., \& Morell, M. (2018). Turismofobia como arma arrojadiza. Ábaco. Revista de Cultura y Ciencias Sociales, 4(98), 55-64.

Brotons, M.M., Murray, I., \& Blázquez, M. (2016). Viaje de ida y vuelta, al mito. La contribución del cine a la formación de la iconografia turística de Mallorca. Anales de Geografía de la Universidad Complutense, 36(2), 203-236. https://doi.org/10.5209/aguc.53583

Buswell, R.J. (2007). Majorca and tourism: History, economy and environment. Bristol: Channel View. 
Cabrerizo, C., Rodríguez, G., \& Rodríguez, I. (2011). La imagen de postal y el lugar turístico. Espacios y destinos turísticos en tiempos de globalización y crisis. Actas del Coloquio de Geografía del turismo, ocio $y$ recreación (pp. 187-202). Madrid: AGE. https://doi.org/10.15366/esmx.turismo2015.002

Casano, F. (2005 [1996]). Il pensiero meridiano. Bari: Editori Laterza.

Colom-Montero, G. (2019). Mass tourism as cultural traume: An analysis of the Majorcan comics Els darrers dies de l'Imperi Mallorquí (2014) and Un infern a Mallorca (La decadència de l'Imperi Mallorquí (2018). Studies in Comics, 10(1), 49-71. https://doi.org/10.1386/stic.10.1.49_1

Crawshaw, C., \& Urry, J. (1997). Tourism and the photographic eye. In C. Rojek \& J. Urry (Eds.). Touring cultures: Transformations of travel and theory (pp. 176-195). London \& New York: Routledge. https://doi.org/10.2307/2655572

Duke, P. (2007). The tourist gaze, the Cretans glance. New York: Routledge.

Fabian, J. (1983). Time and the other: How anthropology makes its object. New York: Columbia University Press.

Foucault, M. (1969). Michel Foucault explique son dernier livre. Interview with J. J. Brochier. Magazine littéraire, 28, 23-25.

Grydehøj, A., Nadarajah, Y., \& Markussen, U. (2020). Islands of indigeneity: Cultural distinction, indigenous territory and island spaciality, Area, 52(1), 14-20. https://doi.org/10.1111/area.12520

Hay, P. (2006). A phenomenology of islands. Island Studies Journal, 1(1), $19-42$.

Horrach, B. (2015). Aprendiendo de la balearización. Mallorca, un laboratorio internacional del turismo de masas y de la conformación de los destinations maduros litorales (Doctoral dissertation, Universitat Politècnica de Catalunya, Barcelona, Spain). Retrieved from https://www.tdx.cat/handle/10803/384617

Jeffers, D. (2008). Postcolonial resistance: Culture, liberation, and transformation. Toronto: University of Toronto Press.

Johnson, H. (2012). 'Genuine Jersey': Branding and authenticity in a small island culture. Island Studies Journal, 7(2), 235-258.

Joseph, C.A., \& Kavoori, A.P. (2001). Mediated resistance: Tourism and the host community. Annals of Tourism Research, 28(4), 998-1009. https://doi.org/10.1016/s0160$\underline{7383(01) 00005-6}$

King, E.M.B. (1997). Creating island resorts. London: Routledge.

Lessing, G.E. (1989 [1766]). Laocoonte. Madrid: Tecnos.

Martín de la Rosa, B. (2003). La imagen turística de las regiones insulares: Las islas como paraísos. Cuadernos de Turismo, 11, 127-137. https://doi.org/10.6018/turismo.41.327111

Martínez-Tejero, C. (2018). Contesting present-day Lisbon through art: Neoliberal city and cultural resistance. In D. Wieser \& A.F. Prata (Eds.). Cities of the Lusophone world, (pp. 217-236). Oxford: Peter Lang.

Morell, M. (2018). Urban tourism via dispossession of oeuvres: Labor as a common denominator. Focaal: Journal of Global and Historical Anthropology, 82, 35-48. https://doi.org/10.3167/fcl.2018.820103

Moyà, E. (2015). Palma: The oscillating core of a suspended periphery: An imagologic approach to an island city and its discourse of pleasure. Journal of Marine and Island Cultures, 4, 1-9. https://doi.org/10.1016/j.imic.2015.06.001 
Moyà, E. (2017). Journeys in the sun: Travel literature and desire in the Balearic Islands (1903-1939). Bern: Peter Lang. https://doi.org/10.3726/b11413

Murray, I., Yrigoy, I., \& Blázquez-Salom, M. (2017). The role of crises in the production, destruction and restructuring of tourist spaces: The case of the Balearic Islands. Revista Investigaciones Turísticas, 13, 1-29. https://doi.org/10.14198/inturi2017.13.01

Parcerisas, P. (2007). Conceptualismo(s) poéticos, políticos y periféricos. En torno al arte conceptual en España, 1964-1980. Madrid: Akal.

Pèrcopo, L. (2011). On the trail of the post-colonial: Transcultural spaces, cosmopolitanism, and the islands of the Mediterranean. New Literatures Review, 47-48, 91-110.

Picornell, M. (2010). Palma, ciutat oberta? Estaticitat i mobilitat en les representacions d'una ciutat cruilla. Journal of Catalan Studies, 13, 129-175.

Pulitano, E. (2016). Paradise islands, wild nature, and the contemporary tourist gaze re/locating the Caribbean. In E. Pulitano (Ed.), Transnational Narratives from the Caribbean: Diasporic Literature and the Human Experience (pp. 149-158). London \& New York: Routledge. https://doi.org/10.4324/9781315658513

Riera, P.J. (2017). Memòria selectiva. Postals dibuixades de Mallorca al límit. Palma: Disset edició. Rojek, C. (1997). Indexing, fragging and the social construction of tourist sights. In C. Rojek \& J. Urry (Eds.), Touring Cultures. Transformations of Travel and Theory (pp. 52-74). London \& New York: Routledge. https://doi.org/10.4324/9780203427736

Sala, E., \& Casellas, A. (2015). El pensament únic a través de la publicitat i l'homogeneització de la identitat territorial: un estudi de cas de les Illes Balears. Treballs de la Societat Catalana de Geografia, 79, 295-310. https://doi.org/10.1515/9783110297690.75

Said, E. (1996 [1993]). Cultura e imperialismo. Barcelona: Anagrama.

Urry, J. (2002 [1990]). The tourist gaze. London: Sage.

Valdivielso, J., \& Moranta, J. (2019). The social construction of the tourism degrowth discourse in the Balearic Islands. Journal of Sustainable Tourism, 27(12), 1876-1892. https://doi.org/10.1080/09669582.2019.1660670

Vives, F. (2012). Paradise of Love o l'illa imaginada: música i turisme a la Mallorca dels anys seixanta. Palma: Documenta Balear.

Vives-Miró, S., \& Rullán, O. (2017). ¿Desposesión de vivienda por turistización? Revalorización y desplazamientos en el Centro Histórico de Palma (Mallorca). Revista de Geografía Norte Grande, 67. https://doi.org/10.4067/s0718-34022017000200004

Winiwarter, V. (2008). Nationalized nature on picture postcards: Subtexts of tourism from an environment perspective. Global Environment, 1(1), 192-215. https://doi.org/10.3197/ge.2008.010108 
Mercè Picornell 